\title{
Front Matter: Volume 7346
}

, "Front Matter: Volume 7346," Proc. SPIE 7346, Visual Analytics for Homeland Defense and Security, 734601 (14 May 2009); doi: $10.1117 / 12.830589$

SPIE Event: SPIE Defense, Security, and Sensing, 2009, Orlando, Florida, United SPIE. States 


\title{
PROCEEDINGS OF SPIE
}

\section{Visual Analytics for Homeland Defense and Security}

\author{
William J. Tolone \\ William Ribarsky \\ Editors
}

14 April 2009

Orlando, Florida, United States

Sponsored and Published by

SPIE 
The papers included in this volume were part of the technical conference cited on the cover and title page. Papers were selected and subject to review by the editors and conference program committee. Some conference presentations may not be available for publication. The papers published in these proceedings reflect the work and thoughts of the authors and are published herein as submitted. The publisher is not responsible for the validity of the information or for any outcomes resulting from reliance thereon.

Please use the following format to cite material from this book:

Author(s), "Title of Paper," in Visual Analytics for Homeland Defense and Security, edited by William J. Tolone, William Ribarsky, Proceedings of SPIE Vol. 7346 (SPIE, Bellingham, WA, 2009) Article CID Number.

ISSN 0277-786X

ISBN 9780819476128

Published by

SPIE

P.O. Box 10, Bellingham, Washington 98227-0010 USA

Telephone +1 3606763290 (Pacific Time) · Fax +1 3606471445

SPIE.org

Copyright (C) 2009, Society of Photo-Optical Instrumentation Engineers

Copying of material in this book for internal or personal use, or for the internal or personal use of specific clients, beyond the fair use provisions granted by the U.S. Copyright Law is authorized by SPIE subject to payment of copying fees. The Transactional Reporting Service base fee for this volume is $\$ 18.00$ per article (or portion thereof), which should be paid directly to the Copyright Clearance Center (CCC), 222 Rosewood Drive, Danvers, MA 01923. Payment may also be made electronically through CCC Online at copyright.com. Other copying for republication, resale, advertising or promotion, or any form of systematic or multiple reproduction of any material in this book is prohibited except with permission in writing from the publisher. The CCC fee code is 0277-786X/09/ $\$ 18.00$.

Printed in the United States of America.

Publication of record for individual papers is online in the SPIE Digital Library.

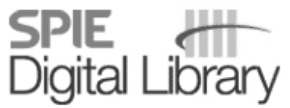

SPIEDigitalLibrary.org

Paper Numbering: Proceedings of SPIE follow an e-First publication model, with papers published first online and then in print and on CD-ROM. Papers are published as they are submitted and meet publication criteria. A unique, consistent, permanent citation identifier (CID) number is assigned to each article at the time of the first publication. Utilization of CIDs allows articles to be fully citable as soon they are published online, and connects the same identifier to all online, print, and electronic versions of the publication. SPIE uses a six-digit CID article numbering system in which:

- The first four digits correspond to the SPIE volume number.

- The last two digits indicate publication order within the volume using a Base 36 numbering system employing both numerals and letters. These two-number sets start with 00, 01, 02, 03, 04, $05,06,07,08,09,0 A, 0 B \ldots 0 Z$, followed by 10-1Z, 20-2Z, etc.

The CID number appears on each page of the manuscript. The complete citation is used on the first page, and an abbreviated version on subsequent pages. Numbers in the index correspond to the last two digits of the six-digit CID number. 


\section{Contents}

$\checkmark$ Conference Committee

\section{SESSION 1 INFRASTRUCTURE PROTECTION, INCIDENT RESPONSE, AND PUBLIC SAFETY}

734602 Recommendation-based geovisualization support for reconstitution in critical infrastructure protection [7346-01]

D. C. Wilson, O. Pala, W. J. Tolone, W.-N. Xiang, The Univ. of North Carolina at Charlotte (United States)

734603 Visual analytics for law enforcement: deploying a service-oriented analytic framework for web-based visualization [7346-02]

S. T. Dowson, J. Bruce, D. M. Best, R. M. Riensche, L. Franklin, W. A. Pike, Pacific Northwest National Lab. (United States)

734604 Towards sustainable infrastructure management: knowledge-based service-oriented computing framework for visual analytics [7346-03]

R. Vatcha, S.-W. Lee, A. Murty, W. Tolone, X. Wang, W. Dou, R. Chang, W. Ribarsky, W. Liu,

S.-E. Chen, E. Hauser, The Univ. of North Carolina at Charlotte (United States)

734605 Analyzing networks of static and dynamic geospatial entities for urban situational awareness [7346-04]

D. Sherrill, M. Yee, P. Cho, MIT Lincoln Lab. (United States)

$734606 \quad$ Knowledge integrated visual analysis system for in-depth management of bridge safety and maintenance [7346-05]

X. Wang, W. Dou, R. Vatcha, W. Liu, S.-E. Chen, S.-W. Lee, R. Chang, W. Ribarsky, The Univ. of North Carolina at Charlotte (United States)

\section{SESSION 2 MARITIME SURVEILLANCE AND PORT SECURITY}

734607 VISAD: an interactive and visual analytical tool for the detection of behavioral anomalies in maritime traffic data [7346-06]

M. Riveiro, G. Falkman, T. Ziemke, Univ. of Skövde (Sweden); H. Warston, Saab Microwave Systems AB (Sweden)

734608 A semantic based video indexing and retrieval system for maritime surveillance [7346-07] H. T. Nguyen, P. Ramu, X. Liu, H. Wei, J. Yadegar, UtopiaCompression Corp. (United States)

734609 Adaptive maritime video surveillance [7346-08]

K. M. Gupta, Knexus Research Corp. (United States); D. W. Aha, R. Hartley, Naval Research Lab. (United States); P. G. Moore, Knexus Research Corp. (United States) 
7346 OA Reasoning about anomalies: a study of the analytical process of detecting and identifying anomalous behavior in maritime traffic data [7346-09]

M. Riveiro, G. Falkman, T. Ziemke, Univ. of Skövde (Sweden); T. Kronhamn, Saab Microwave

Systems AB (Sweden)

\section{SESSION 3 INTEGRATION AND INTERACTION IN SUPPORT OF DEFENSE AND SECURITY}

$7346 \mathrm{OB} \quad$ Visualization as integration of heterogeneous processes [7346-10]

X. Wang, W. Dou, W. Ribarsky, R. Chang, The Univ. of North Carolina at Charlotte (United States)

7346 OC Integrating time-series visualizations within parallel coordinates for exploratory analysis of incident databases [7346-11]

M. Butkiewicz, Univ. of Pittsburgh (United States); T. Butkiewicz, W. Ribarsky, R. Chang, The Univ. of North Carolina at Charlotte (United States)

7346 OD Hierarchical multi-touch selection techniques for collaborative geospatial analysis [7346-12]

T. Butkiewicz, D. H. Jeong, Z. Wartell, W. Ribarsky, R. Chang, The Univ. of North Carolina at Charlotte (United States)

$7346 \mathrm{OE} \quad$ Human behavior digitization and intent recognition using data modeling [7346-13] H. M. Jaenisch, J. W. Handley, Licht Strahl Engineering Inc. (United States) and Amtec Corp. (United States); K. L. Jaenisch, Licht Strahl Engineering Inc. (United States); N. G. Albritton, Amtec Corp. (United States)

Author Index 


\title{
Conference Committee
}

\author{
Symposium Chair
}

Ray O. Johnson, Lockheed Martin Corporation (United States)

Symposium Cochair

Michael T. Eismann, Air Force Research Laboratory (United States)

Conference Chairs

William J. Tolone, The University of North Carolina at Charlotte (United States)

William Ribarsky, The University of North Carolina at Charlotte (United States)

Program Committee

Bruce Campbell, University of Washington (United States)

John Dill, Simon Fraser University (Canada)

David S. Ebert, Purdue University (United States)

Brian Fisher, Simon Fraser University (Canada)

John Gerth, Stanford University (United States)

Ashok K. Goel, Georgia Institute of Technology (United States)

Robert Kosara, The University of North Carolina at Charlotte (United States)

William Pike, Pacific Northwest National Laboratory (United States)

Anita Raja, The University of North Carolina at Charlotte (United States)

Anthony Robinson, Pennsylvania State University (United States)

Antonio Sanfilippo, Pacific Northwest National Laboratory (United States)

John Stasko, Georgia Institute of Technology (United States)

Matthew 0 . Ward, Worcester Polytechnic Institute (United States)

Pak Chung Wong, Pacific Northwest National Laboratory (United States)

Jing Yang, The University of North Carolina at Charlotte (United States)

\section{Session Chairs}

1 Infrastructure Protection, Incident Response, and Public Safety William J. Tolone, The University of North Carolina at Charlotte

(United States) 
2 Maritime Surveillance and Port Security

William Ribarsky, The University of North Carolina at Charlotte (United States)

3 Integration and Interaction in Support of Defense and Security William J. Tolone, The University of North Carolina at Charlotte (United States) 